\title{
Studies on Porcine Pancreatic Elastase Activity. I. Radioimmuoassay of Porcine Pancreatic Elastase
}

\author{
Yasuyuki Nakajima, Seiki Matsuno, Noboru Noto, \\ Yoichi SaItoh and Toshio Sato \\ The First Department of Surgery, Tohoku University School of \\ Medicine, Sendai 980
}

\begin{abstract}
Nakajima, Y., Matsuno, S., Noto, N., SaItoh, Y. and Sato, T. Studies on Porcine Pancreatic Elastase Activity. I. Radioimmunoassay of Porcine Pancreatic Elastase. Tohoku J. exp. Med., 1980, 131 (2), 119-126 - An improved method of radioimmunoassay was devised to offer a successful formula for determining blood concentration of elastase. With porcine pancreatic elastase as the antigen, rabbits were immunized to obtain antiserum. Iodinated elastase labeled by the chloramine$T$ procedure using ${ }^{131} \mathrm{I}$ (or ${ }^{125} \mathrm{I}$ ) had a specific activity of $200-300 \mathrm{mCi} / \mathrm{mg}$. The double antibody method was used for BF separation. While the usual method of radioimmunoassay was not always successful in obtaining accurate serum concentration of elastase, the use of diisopropyl fluorophosphate (DFP) was able to eliminate the disturbing influence of intra-serous inhibitors, $\alpha_{1}$.AT and $\alpha_{2}-\mathrm{M}$, eventually producing satisfactory results. With the use of DFP, the elastase standard curve and the porcine serum dilution curve had a statistically significant correlation; precision and recovery were both satisfactory; cross-reactivity of the antiserum with trypsin and chymotrypsin was less than $0.001 \%$. The minimal detectable concentration of elastase was $5 \mathrm{ng} / \mathrm{ml}$, and the range of normal fasting porcine serum level was $70-100 \mathrm{ng} / \mathrm{ml}$. porcine pancreatic elastase; radioimmunoassay; diisopropyl fluorophosphate
\end{abstract}

Elastase is clinically known to have a close relation to arteriosclerosis (Loeven 1969) and acute pancreatitis (Geokas et al. 1968a) for its two functions of proteolysis and elastolysis. Especially in acute pancreatitis, elastase is suspected to destroy elastic fiber on the wall of the pancreatic blood vessel, aggravating the disease into hemorrhagic or necrotic pancreatitis (Satake et al. 1974). For the quantitation of elastase, a variety of methods have been reported: using Congo red-elastin (Hall 1966), DNS-elastin (Rinderknecht et al. 1968) or other elastin substrates (Geokas et al. 1968b), or employing various synthetic substrates specific to elastase, being joined recently by radioimmunoassay (Caraballo et al. 1974). But these methods are only applicable for elastase in pancreatic juice and tissue. In the blood, the intervention of $\alpha_{1}$-antitrypsin $\left(\alpha_{1}-\mathrm{AT}\right)$ and $\alpha_{2}$-macroglobulin $\left(\alpha_{2}-\mathrm{M}\right)$ results in inhibition of the activity of the elastase, and therefore, no reliable method has so far been established to determine serum elastase. Now we have found that the influence of such inhibitors could be eliminated by employing diisopropyl fluorophosphate (DEP) and developed a fairly satisfactory method of radio-

Received for publication, March 28, 1979. 
immunoassay (R.I.). This report offers a summary of our improved method of R.I.

\section{Materials and Methods}

${ }^{131} I$ (or ${ }^{125} I$ )-labeled elastase. Elastase was labeled with $\mathrm{Na}^{131} \mathrm{I}$ (or $\mathrm{Na}^{125} \mathrm{I}$ ) obtained from the New England Nuclear Co., Boston, by the method of Greenwood et al. (1963), and the labeled preparation was refined by gel filtration with a column of Sephadex G-50 $(1.5 \times 45 \mathrm{~cm})$ equilibrated with $0.05 \mathrm{M}$ phosphate buffer, $\mathrm{pH} 7.5$.

Anti-porcine pancreatic elastase serum. The rabbit antielastase antibody was produced in rabbits by successive injections at 1 week intervals for 5 weeks with $2 \mathrm{mg}$ of three times crystallized porcine pancreatic elastase which was produced by Eizai Pharm. Co., Tokyo, emulsified in complete Freund's adjuvant obtained from Sanko Junyaku, Tokyo. After five times of immunization, the blood was drawn from the ear vein and centrifuged to obtain antiserum which was stored at $-20^{\circ} \mathrm{C}$.

Reagents for radioimmunoassay. Gout anti-rabbit globulin serum and normal rabbit serum were obtained from Eiken Kagaku Co., Tokyo. Diisopropyl fluorophosphate (DFP) was obtained from Koch-Light Lab., London; bovine pancreatic trypsin was from Sigma Co., St. Louis; bovine pancreatic alpha chymotrypsin was from P-L Biochemicals, Milwaukee; enterokinase was from Sanko Junyaku, Tokyo.

Methods of radioimmunoassay (R.I.). R.I. 1. All reagents were diluted with standard radioimmunoassay buffer containing $0.5 \mathrm{M}$ phosphate buffer, pH 7.5 , and $0.2 \%$ $(\mathrm{W} / \mathrm{V})$ bovine serum albumin. After addition of standard buffer to make final volume of $0.7 \mathrm{ml}$, the following reagents were added, in the order indicated, 0 to $100 \mathrm{ng} / 0.1 \mathrm{ml}$ of standard elastase or serum sample, $0.1 \mathrm{ml}$ of elastase antiserum diluted 1:50,000 with standard buffer, and $0.1 \mathrm{ml}$ of ${ }^{131} \mathrm{I}-\left(\mathrm{or}^{125} \mathrm{I}\right)$ labeled elastase $(10,000 \mathrm{cpm})$. After incubation for 2 days at $4^{\circ} \mathrm{C}$, bound and free labeled antigen were separated by the duoble antibody procedure. An aliquot of $0.1 \mathrm{ml}$ of gout anti-rabbit globulin serum and normal rabbit serum were added to each assay tube, followed by incubation for $24 \mathrm{hr}$ at $24^{\circ} \mathrm{C}$. Bound fraction was then isolated by centrifugation for $30 \mathrm{~min}$ at $3,000 \mathrm{rpm}$ which was counted by $\alpha$-scintillation system.

R.I. 2. After incubation of $0.1 \mathrm{ml}$ of ${ }^{131} \mathrm{I}$-(or ${ }^{125} \mathrm{I}$ ) labeled elastase and $0.1 \mathrm{ml}$ of elastase antiserum diluted 1:50,000 with $0.4 \mathrm{ml}$ of standard buffer for $24 \mathrm{hr}$ at $4^{\circ} \mathrm{C}, 0.1 \mathrm{ml}$ of standard elastase or serum sample was added followed by incubation for $72 \mathrm{hr}$ at $4^{\circ} \mathrm{C}$. Then BF separation was performed by double antibody procedure in the same way as described in R.I. 1 .

R.I. 3. All procedures were performed in the same manner as described in R.I. 1, except addition of $10^{-3} \mathrm{M}$ DFP in the standard buffer.

Esterolytic activity of elastase. Esterolytic activity of elastase was determined by a pH-stat autotitrator (Radiometer Co.) at room temperature using $20 \mathrm{mM} \mathrm{N}$-benzoyl-L. alanine methylester (BAME) obtained from Aldrich Chem. Co., Milwaukee, dissolved in 0.01 M Tris-HCl buffer, $\mathrm{pH} 8.0$, as substrate. The unit of esterolytic activity was expressed in BAME $\mu \mathrm{mole} / \mathrm{min} / \mathrm{mg}$. Inhibition of esterolytic activity of elastase by DFP was studied with different concentrations of DFP.

\section{RESULTS}

Gel filtration. The elution pattern of radioactivity showed two peaks, of which the first peak (A) was confirmed as ${ }^{131}$ I-labeled elastase and the second peak (B) as free ${ }^{131} \mathrm{I}$ by determination of reaction of $\mathrm{A}$ or $\mathrm{B}$ and antielastase serum. The radioactive labeled elastase obtained had a specific activity of $200-300 \mathrm{mCi} / \mathrm{mg}$ (Fig. 1).

Anti-elastase serum. Titer of anti-elastase serum was confirmed by Ouch- 


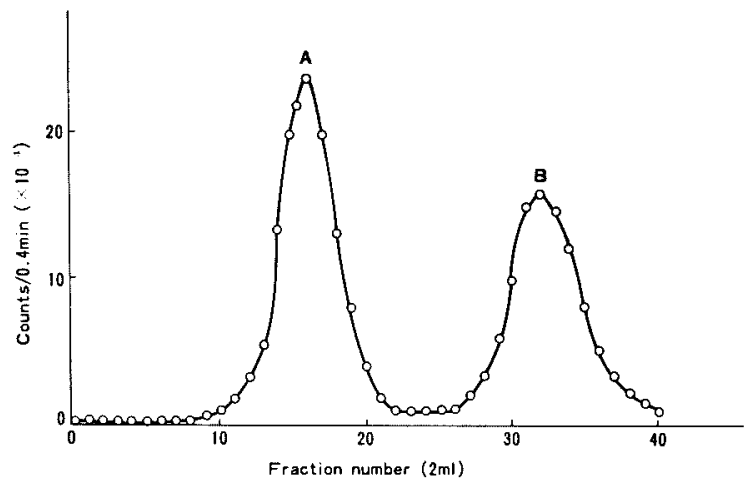

Fig. 1. Fractionation of ${ }^{131}$ I-elastase on sephadex G-50.

The ellution pattern of radioactivity showed two peaks. First peak, A, was confirmed as ${ }^{131} \mathrm{I}$-abeled elastase and second peak, B, as free ${ }^{131} \mathrm{I}$ by the reaction of anti-elastase serum.

terlony's method (1948), and the final dilution was 350,000 fold in this radioimmunoassay system.

R.I. 1. The reaction of ${ }^{131}$ I-labeled elastase and different concentration of anti-elastase serum showed a parabola with a peak at 1,000-fold dilution of antielastase serum, and the standard curve also showed a parabola with a peak at $1 \mathrm{ng} /$ $\mathrm{ml}$ of standard elastase. Therefore, this method of radioimmunoassay was proved inadequate.

R.I. 2. The standard curve and porcine serum dilution curve showed almost parallel and seemed to be an adequate assay. However, the coefficient of variations of inter and intra assay precision was around $30 \%$, and recovery rate was only around $10 \%$. Therefore, this method was also proved still inadequate.

R.I. 3. Incubation at room temperature resulted in less precipitation of ${ }^{131} \mathrm{I}$ labeled elastase than incubation at $4^{\circ} \mathrm{C}$, and incubation at $\mathrm{pH} 7.5$ resulted in most precipitation of ${ }^{131}$ I-labeled elastase. Effect of incubation time of the first and second reaction resulted in a plateau after $48 \mathrm{hr}$ and $24 \mathrm{hr}$. The standard curve and porcine serum dilution curve were parallel, which indicated statistically significant correlation between the theoretical value $X$ and the measured value $Y$ of elastase by $Y=1.015 X-3.603, \gamma=0.988, p<0.01$ (Fig. 2). The minimal detectable concentration of elastase was $5 \mathrm{ng} / \mathrm{ml}$. Cross-reactions with other pancreatic enzymes were also studied with this method. No cross-reactivity has been observed with trypsin, chymotrypsin or enterokinase (Fig. 3). Inter-assay precision and intra-assay precision were studied in this assay. The coefficients of variations of the both precisions were mostly less than $10 \%$ (Tables 1 and 2). Recovery rate was $83 \%$ to $95 \%$ ('Table 3). By contrast, when the exogenous elastase dissolved in standard buffer without DFP was added to this assay system, average recovery rate obtained was around $20 \%$ which suggested that exogenous elastase is bound to serum inhibitors $\alpha_{1}$-antitrypsin and $\alpha_{2}$-macroglobulin. 


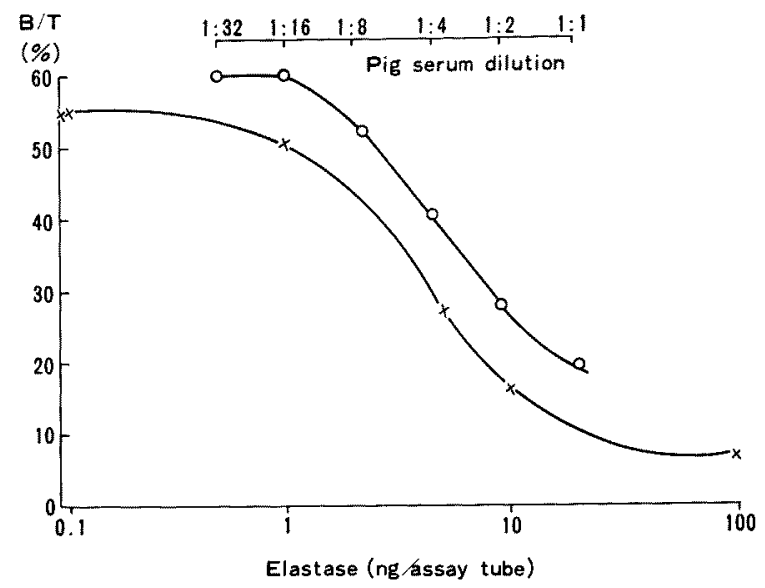

Fig. 2. Elastase standard curve and pig serum dilution curve.

The method of radioimmunoassay was described under "Materials and Methods". $x-x$, porcine pancreatic standard elastase; $0-0$, pooled normal porcine serum diluted until $1: 32$ with standard buffer.

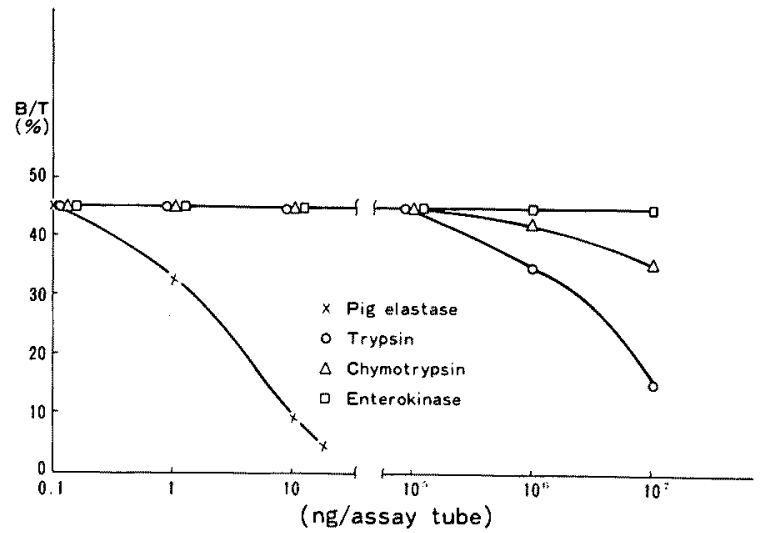

Fig. 3. Cross-reactivity of various proteases with elastase antiserum. No cross-reaction was seen with trypsin, chymotrypsin, or enterokinase within usual assay concentration of elastase.

TABLE 1. Inter-assay precision obtained by R.I. 3

\begin{tabular}{cccc}
\hline & \multicolumn{4}{c}{ Serum elastase $(\mathrm{ng} / \mathrm{ml})$} \\
\cline { 2 - 4 } No. & $\mathrm{A}$ & $\mathrm{B}$ & $\mathrm{C}$ \\
\hline 1 & 15 & 38 & 74 \\
2 & 16 & 38 & 80 \\
3 & 18 & 41 & 83 \\
Mean \pm s.D. & $16.3 \pm 1.2$ & $39.0 \pm 1.4$ & $79 . \mathrm{C} \pm 3.7$ \\
Coefficient of variation (\%) & 7.4 & 3.6 & 4.7 \\
\hline
\end{tabular}


TABLe 2. Intra-assay precision obtained by R.I. 3

\begin{tabular}{ccccc}
\hline & \multicolumn{5}{c}{ Serum elastase (ng/ml) } \\
\cline { 2 - 5 } No. & $\mathrm{A}$ & $\mathrm{B}$ & $\mathrm{C}$ & $\mathrm{D}$ \\
\hline 1 & 16 & 38 & 76 & 150 \\
2 & 13 & 41 & 74 & 185 \\
3 & 15 & 37 & 76 & 186 \\
4 & 16 & 38 & 76 & 180 \\
5 & 15 & 39 & 90 & 150 \\
6 & 19 & 35 & 73 & 140 \\
7 & 18 & 41 & 70 & 160 \\
Mean \pm s.D. & $16.1 \pm 1.8$ & $38.4 \pm 1.9$ & $76.4 \pm 5.9$ & $164.5 \pm 17.2$ \\
Coefficient of variation (\%) & 11.1 & 4.9 & 7.7 & 10.5 \\
\hline
\end{tabular}

TABLE 3. Accuracy and recovery obtained by R.I. 3

\begin{tabular}{|c|c|c|c|c|c|}
\hline Sample & $\begin{array}{c}\text { Mean } \\
(\mathrm{ng} / \mathrm{ml})\end{array}$ & $\begin{array}{l}\text { Elastase added } \\
(\mathrm{ng} / \mathrm{ml})\end{array}$ & $\begin{array}{l}\text { Mean } \pm \text { s.D. } \\
(\mathrm{ng} / \mathrm{ml})\end{array}$ & Recovery (\%) & $\begin{array}{c}\text { Mean recovery } \\
(\%)\end{array}$ \\
\hline A & 12.0 & $\begin{array}{r}50 \\
100 \\
200\end{array}$ & $\begin{array}{r}53.0 \pm 5.5 \\
103.5 \pm 15.8 \\
163.8 \pm 17.8\end{array}$ & $\begin{array}{l}82.0 \\
91.5 \\
75.9\end{array}$ & 83.1 \\
\hline B & 26.3 & $\begin{array}{r}50 \\
100 \\
200\end{array}$ & $\begin{array}{r}78.8 \pm 7.4 \\
120.0 \pm 9.4 \\
195.0 \pm 3.5\end{array}$ & $\begin{array}{r}105.5 \\
93.7 \\
84.4\end{array}$ & 94.4 \\
\hline $\mathrm{C}$ & 76.0 & $\begin{array}{r}50 \\
100 \\
200\end{array}$ & $\begin{array}{l}123.7 \pm 5.4 \\
183.8 \pm 11.4 \\
241.3 \pm 11.4\end{array}$ & $\begin{array}{r}95.6 \\
107.8 \\
82.7\end{array}$ & 95.4 \\
\hline
\end{tabular}

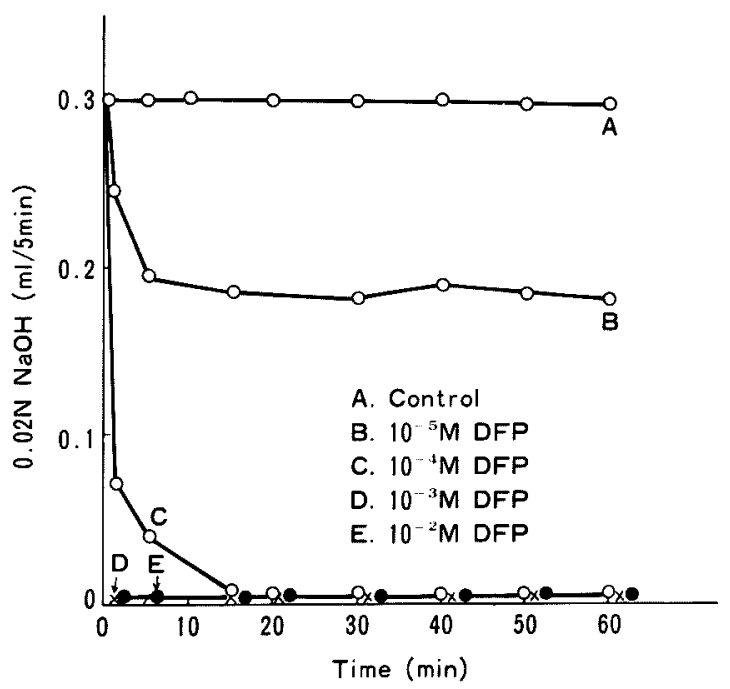

Fig. 4. Inhibition by DFP of esterolytic activity of elastase.

$1 \times 10^{-4} \mathrm{M}$ DFP (C in the figure) inhibited the esterolytic activity of elastase within $20 \mathrm{~min}$ and $1 \times 10^{-3} \mathrm{M}$ DFP (D) and $1 \times 10^{-2} \mathrm{M}$ DFP (E) inhibited the esterolytic activity of elastase within several min. 
Inhibition by DFP of esterolytic activity of elastase. Inhibition of esterolytic activity of elastase was studied with different concentrations of DFP. DFP of $10^{-4}$ $\mathrm{M}$ inhibited the esterolytic activity of elastase completely within $20 \mathrm{~min}$, and DFP of more than $10^{-3} \mathrm{M}$ inhibited the activity completely within several min (Fig. 4).

Furthermore, incubation of ${ }^{131}$ I-labeled elastase and anti-elastase serum with different concentrations of DFP in the standard buffer resulted in a plateau of precipitation of ${ }^{131} \mathrm{I}$-labeled elastase at DFP concentrations of more than $10^{-4} \mathrm{M}$. These results suggest that elastase which was bound with DFP holds immunoreactivity despite that the enzyme activity was completely inhibited.

\section{Discussion}

Elastase, like trypsin and chymotrypsin, belongs to serine proteinase, and is an endopetidase with a molecular weight of 25,900 (Shotton and Hartley 1970). This enzyme is secreted from the pancreas as proelastase and activated by trypsin to become elastase. The activity of elastase has so far been determined using a variety of elastin (Hall 1966; Rinderknecht et al. 1968), and a synthetic substrate as substrate (Bieth and Wermuth 1973). Although these procedures are fairly useful for determining the activity of elastase in pancreatic juice, duodenal juice, and pancreatic tissue (Geokas and Rinderknecht 1974), they cannot be used for elastase in the blood, because elastase is conjugated with an abundance of elastase-inhibitors $\alpha_{1}-\mathrm{AT}$ and $\alpha_{2}-\mathrm{M}$ in the blood, losing its enzymic activity (Turino et al. 1974). Carballo et al. (1974) reported radioimmunoassay for the first time to determine the blood concentration of elastase in the canine pancreas. But their procedure remains doubtful, because they did not consider the inhibitor's influence and did not make the statistical analysis. Geokas et al. (1977) recently extracted elastase from the human pancreas, and eliminated the elastase-inhibitor's influence by using phenylmethane sulfonyl fluoride, and performed radioimmunoassay with satisfactory results.

In our experiments, both of elastase standard curves and antibody dilution curves obtained without use of DFP revealed to be unreasonable and inadequate to be used in determination of elastase concentration in the blood, suggesting interference with intra-serous inhibitors. Although Ooyama et al. (1977) reported that they have been able to eliminate the influence of inhibitors by incubation of the tracer and antibody for $24 \mathrm{hr}$ following addition of standard elastase or serum sample, satisfactory result was not obtained in our own experiment.

Since Kaplan and Dugas (1969) reported BAME as a specific synthetic substrate of elastase, this substance has been used as a substrate for determing esterolytic activity of elastase. It is also known that a serine enzyme inhibitor DFP can inhibit esterolysis of BAME (Naughton and Sanger 1961). Our experiment has shown that DFP of more than $10^{-3} \mathrm{M}$ can inhibit esterolytic activity of elastase completely within several min without any interference with immunoreactivity of elastase. On the basis of the result that elastase bound with DFP still holds 
immunoreactivity despite showing no enzymatic activity, we performed radioimmunoassay with satisfactory result of inter-assay precision, intra-assay precision and recovery rate. The usual concentration of elastase in porcine serum obtained by our R.I. ranged $70 \sim 100 \mathrm{ng} / \mathrm{ml}$; these values are almost equivalent to the level in human serum recently identified by Geokas et al. (1977) and only 1/10 of the values so far reported (Satake et al. 1974; Rinderknecht et al. 1968). However, there are reports that serum elastase is conjugated with $\alpha_{1}-\mathrm{AT}$ and $\alpha_{2}-\mathrm{M}$, and only $\alpha_{1}$-AT-elastase shows a cross-reaction with the antibody (Geokas et al. 1977; Katayama and Fujita 1974), implying insufficiency in clinical applicability of this method for the determination of the concentration of total serum elastase, because the ratio of $\alpha_{2}$-M-elastase relative to $\alpha_{1}$-AT-elastase in the serum is unknown. Nevertheless, Baumstark (1967) reported that about $90 \%$ of elastase in serum are conjugated with $\alpha_{1}$-AT, and, therefore, the determination of $\alpha_{1}$-AT-elastase may give a reliable information for a general trend of total serum elastase. Furthermore, Geokas et al. (1977) reported that no cross-reaction was seen in either porcine pancreatic elastase antibody with human pancreatic elastase or human pancreatic elastase antibody with porcine pancreatic elastase. So, we are now making efforts to study the concentration of human serum elastase.

\section{Acknowledgment}

We express acknowledgment to Dr. Koichi Katayama of the Eisai Co. (Research and Development Division) and Dr. Toshiro Ooyama of the Department of Internal Medicine, Tokyo Metropolitan Geriatric Hospital, for their kindness in providing us with porcine pancreatic elastase material and useful advice about the method of determination.

\section{References}

1) Baumstark, J.S. (1967) Studies on the elastase-serum protein interaction. I. Molecular identity of the inhibitors in human serum and direct demonstration of inhibitor-elastase complexes by zone and immunoelectrophoresis. Arch. Biochem. Biophys., 118, 619-630.

2) Bieth, J. \& Wermuth, C.G. (1973) The action of elastase on p-nitroanilide substrates. Biochem. biophys. Res. Comm., 53, 383-390.

3) Carballo, J., Kasahara, K., Appert, H.E. \& Howard, J.M. (1974) Radioimmunoassay of plasma elastase. Proc. Soc. exp. Biol. Med., 146, 997-1002.

4) Geokas, M.C. \& Rinderknecht, H. (1974) Free proteolytic enzymes in pancreatic juice of patients with acute pancreatitis. Digest. Dis., 19, 591-598.

5) Geokas, M.C., Murphy, D.R. \& Mckenna, R.D. (1968a) The role of elastase in acute pancreatitis. Arch. Path., 86, 117-126.

6) Geokas, M.C., Rinderknecht, H., Lillard, Y. \& Haverback, B.J. (1968b) Elastase in human pancreas. Clin. Biochem., 1, 331-334.

7) Geokas, M.C., Brodrick, J.W., Johnson, J.H. \& Largman, C. (1977) Pancreatic elastase in human serum determination by radioimmunoassay. J. biol. Chem., 252, 61-67.

8) Greenwood, F.C., Hunter, W.M. \& Glover, J.S. (1963) The preparation of ${ }^{131}$ I-labelled human growth hormone of high specific radioactivity. Biochem. J., 89, 114-123.

9) Hall, D.A. (1966) The identification and estimation of elastase in serum and plasma. Biochem. J., 101, 29-36.

10) Kaplan, H. \& Dugas, H. (1969) Evidence that the activity of elastase is not dependent 
on the ionization of its N-terminal amino group. Biochem. biophys. Res. Comm., 34, 681685 .

11) Katayama, K. \& Fujita, T. (1974) Studies on biotransformation of elastase. III. Effects of elastase-binding proteins in serum on the disappearance of ${ }^{131}$ I-labelled elastase from blood. Biochem. biophys. Acta., 336, 165-177.

12) Loeven, W.A. (1969) Human pancreatic enzymes and atheroselerosis and lung emphysema in elderly people. J. Atheroscler. Res., 10, 379-390.

13) Naughton, M.A. \& Sanger, F. (1961) Purification and specificity of pancreatic elastase. Biochem. J., 78, 156-163.

14) Ooyama, T., Kawamura, K., Origasa, H. \& Murakami, M. (1977) Radioimmunoassay of porcine pancreatic elastase. Igaku no Ayumi, 101, 22-23. (Japanese)

15) Ouchterlony, 0 . (1948) In vitro method for testing the toxion-producing capacity of diphtheria bacteria. Acta path. microbiol. scand., 25, 186-191.

16) Rinderknecht, H., Geokas, M.C., Silverman, P. \& Haverback, B.J. (1968) Determination of elastolytic activity in blood of normal subjects and patients with acute pancreatitis. Clin. chim. Acta, 19, 89-95.

17) Satake, K., Reichman, J., Carballo, J., Appert, H.E. \& Howard, J.H. (1974) Plasma levels of elastase, trypsin and their inhibitors in bile induced pancreatitis in the dog. Ann. Surg., 179, 58-62.

18) Shotton, D.M. \& Hartley, B.S. (1970) Amino-acid sequence of porcine pancreatic elastase and its homologies with other serine proteinases. Nature, 225, 802-806.

19) Turino, G.M., Hornebeck, W. \& Robert, B. (1974) In vitro effects of pancreatic elastase. I. - studies on the serum inhibitors, ${ }^{1,2}(38178)$. Proc. Soc. exp. Biol. Med., 146, 712-717. 